\title{
Türk Popülasyonunda Tümor Nekroz Faktör Alfa Gen Polimorfizmi (-376) ile Multipl Skleroz Arasındaki İlişki
}

\author{
Association Between Tumor Necrosis Factor Alpha Gene Polymorphism (-376) and Multiple \\ Sclerosis in Turkish Population
}

\author{
Ahmet ARMAN ${ }^{1}$ (D), Hasan ŞİMŞEK ${ }^{1}$ (D), Merve SARIDAL ${ }^{2}$ (D) \\ ${ }^{1}$ Marmara Üniversitesi, Tip Fakültesi, Tibbi Genetik Anabilim Dall, İstanbul, Türkiye \\ ${ }^{2}$ Marmara Üniversitesi, Fen-Edebiyat Fakültesi, Biyoloji Bölümü, İstanbul, Türkiye
}

$\ddot{O} \mathbf{z}$

Bu araştırmanın amacı Multipl Skleroz (MS) ile Tümor Nekroz Faktör-Alfa (TNF-A) geninin promotör bölgesindeki (-376) gen polimorfizmi arasındaki ilişkininin ortaya çıkarılmasıdır. Yapılan çalışmada 100 MS hastası ve 100 sağlıklı kontrol olmak üzere toplam 200 birey incelenmiştir. Bunun için ilk olarak kandan DNA izolasyonu yapılmış ve elde edilen DNA'lardan TNF-A geninin promoter - 376 bölgesi polimeraz zincir reaksiyonu yöntemi ile çoğaltılmıştır. İkinci aşamada ise elde edilen PCR ürünleri Tsp50 enzimi ile kesilerek genotip dağılımları ve allel frekansları incelenmiştir. Türk popülasyonunda MS hastalığı ile TNF-A - 376 polimorfizminin genotip dağılımı arasında kuvvetli bir ilişki bulunmuştur ( $\mathrm{p}=0,010)$. Aynı zamanda TNF-A - 376 polimorfizminin allel frekansı MS hastalığıyla bir ilişki göstermektedir ( $\mathrm{p}=0.011$ ). Bu ilişkide TNF-A - 376 polimorfizminin heterozigot genotip G/A olduğu ve A allelinin koruyucu etkisi olduğu görülmüştür. TNF-A - 376 polimorfizmi ile MS arasında hastalığın risk oluşturması açısından herhangi bir ilişki bulunmamıştır ancak G/A genotipi ve A allelinin sağlıklı kişilerde koruyucu etkisi olabildiği düşünülmektedir.

Anahtar Kelimeler: Promoter, Polymorphism, Tumor Necrosis Factor Alpha (TNF-A), Multiple Sclerosis (MS)

\begin{abstract}
The purpose of this study is the detection of the association between MS and TNF-A gene promoter - 376 polymorphism.In this study, 100 MS patients and 100 healthy controls were examined. Firstly, genomic DNA was extracted from human leukocyte nuclei isolated from whole blood by standard methods and then the promoter region of TNF-A including - 376 polymorphism was amplified with PCR method. Secondly, the PCR products were digested with a digestion enzyme and genotype distributions and allele frequencies were determined. A strong association between MS and TNF-A - 376 genotype distribution was detected $(p=0,010)$. At the same time TNF-A - 376 allele frequency was showed an association with MS ( $p=0,011)$, but this association indicates that GA genotype and A allele have protective effects. There is not an association between TNF-A - 376 polymorphism and MS progression, but GA genotype and A allele may be the protective factors in the healthy people.
\end{abstract}

Keywords: Promoter, Polymorphism, Tumor Necrosis Factor Alpha (TNF-A), Multiple Sclerosis (MS)

\section{GİRIŞ}

MS sık görülen inflamasyon, demiyelinizasyon ve aksonal hasarlı alanlar ile karakterize otoimmün bir hastalıktır [1]. MS etiyolojisi gerçekte iyi bilinmemekle birlikte multifaktöriyel olup genetik, çevresel ve coğrafi faktörler önemli rol almaktadır [2]. Çalışmalar göstermektedir ki TNF-A geninin de lokalize olduğu [3] majör doku uygunluk kompleksi (MHC) sınıf II ve sinıf III genlerinin polimorfizmleri MS duyarlılık, direnç ve klinik formları ile ilişkilidir [4-5]. MS hastaları hastalığın şiddetine göre dört gruba ayrılmıştır: Primer ilerleyen MS (PPMS), ikincil ilerleyen MS (SPMS), yineleyici-düzelen MS (RRMS) ve ilerleyen relap MS (PRMS) [6]. TNF-A geni ürünü olan TNF- $\alpha$ bir proinflamatuar sitokin olup özellikle makrofajlardan sekrete 
olmakta ve hücre proliferasyonu ve farklılaşması, apoptoz, lipid metabolizması ve koagülasyon gibi çok önemli fonksiyonlara sahiptir. Otoimmün hastalıklar, insülin rezistansı ve kanser gibi birçok hastalığın patogenezinde yer almaktadır [7]. Bu yüzden de TNF- $\alpha$, otoimmün bir hastalık olan MS'in ilerlemesinde de önemli bir rol alabilmektedir. TNF$\alpha$ 'nın MS hastalarında beyin omurilik sıvısı (BOS) ve periferik kan düzeylerinin arttığı rapor edilmiş̧ir [8]. Bu yüzden de TNF-A gen yapısındaki değişikliklerin MS hastalığının ilerlemesinde önemli bir rol oynayacağı ileri sürülmektedir. Bugüne kadar TNF-A promotör bölgesinde tek nükleotid polimorfizmleri (SNP) üzerinde durulmuştur ve bu değişikliklerin TNF-A transkripsiyonunu arttırarak hastalığın şiddetinin artmasında önemli rol alacağı düşünülmektedir. TNF-A promotör bölgesindeki SNP'ler $1031 \mathrm{~T} / \mathrm{C},-863 \mathrm{C} / \mathrm{A},-857$ $\mathrm{C} / \mathrm{T},-376 \mathrm{G} / \mathrm{A},-308 \mathrm{G} / \mathrm{A}$, ve - $238 \mathrm{G} / \mathrm{A}$ 'dir [9-10]. TNF-A - 308 G/A polimorfizmi Asya nüfusunda risk oluşturmuş fakat Kafkas nüfusunda risk oluşturmamıştır [11]. TNF-A ve MS arasındaki ilişkinin temel sebebi, TNF- $\alpha$ molekülünün inflamasyonu indükleme özelliğinden kaynaklanmaktadır. Yapılan çalışmalar göstermiştir ki TNF-A geninin yapısında meydana gelen varyasyonlar TNF-A'nın çalışmasını etkilemektedir. Tek nükleotid polimorfizmi olarak adland1rılan varyasyonlar da bunlardan biridir. Molekülün özellikle promotör bölgesindeki polimorfizmlerin, molekülün çalışmasını ve çoğalmasını etkilediği bilinmektedir. Özellikle TNF-A - 376 polimorfizm bölgesinde gen ekspresyonunda rol alan Oct-1 transkripsiyon faktörü bağlanma yeri bulunması ve -376 bölgesi ile ilgili yapılan çalışmaların oldukça az olması [12] bizi, Türk populasyonunda TNF-A geninin promotör bölgesi üzerindeki - $376 \mathrm{G} / \mathrm{A}$ polimorfizmi ile MS arasındaki ilişkiyi incelemeye yöneltmiştir.

\section{MATERYAL VE YÖNTEM}

\subsection{Klinik Testler}

Hastalığın ön tanısı, nöroloji uzmanı tarafından muayene sonrası konmuş olup daha sonra hastanın beyin manyetik rezonans görüntülemesi (MR) yapılmış BOS ve kaydedilmiş potansiyelleri ile hastalığın tanısı kesinleştirilmiştir.

\subsection{Moleküler Biyoloji ile İlgili Testler}

Bu çalışmada, TNF-A promotör bölgesindeki - 376 G/A polimorfizmi bakılmıştır. TNF-A gen polimorfizmlerini belirlemekte kullanılan moleküler biyoloji tekniklerden yararlanılmıştır.

\subsubsection{DNA izolasyonu}

100 normal, 100 MS hastalığı olan toplam 200 bireyden kan alınmış ve daha sonra kandan tuzda çöktürme yöntemi ile manuel olarak DNA'ları izole edilmiştir [13].

\subsubsection{Polimeraz zincir reaksiyonu (PCR)}

TNF-A promotör bölgesindeki değişiklik gösterdiği bilinen bölge PCR yöntemiyle çoğaltılmıştır. PCR işlemi aşağıda anlatıldığı şekilde yapılmıştır.

PCR için gerekli malzemeler:

- $\mathrm{ddH}_{2} \mathrm{O}$

- $10 \mathrm{X}$ reaksiyon tamponu

- $10 \mathrm{pmol} / \mathrm{ml}$ primer çifti

· $200 \mathrm{M}$ dNTP karışımı

. $\quad 1.5 \mathrm{mM} \mathrm{MgCl}_{2}$

. $\quad 0.50$ ünite Taq polimeraz enzimi

Yukardaki malzemelere $2 \mu l^{\prime}$ lik $(50 \mathrm{ng} / \mu \mathrm{l})$ template DNA eklenilmiş ve tüpler PCR cihazına (Techne, TC-312) yerleştirilmiştir. İlk olarak çift sarmal DNA, $94^{\circ} \mathrm{C}$ 'de 3 dakika tutulmuştur. $\mathrm{Bu}$ işlem ile çift zincirli DNA tamamen tek zincir DNA'ya dönüşmesi sağlanmıştır. Sonrasında üç basamaktan oluşan döngü $30 \mathrm{kez}$ tekrarlanmıştır.

\section{PCR Döngüsü:}

- $\quad$ Basamak $1-94^{\circ} \mathrm{C}$ 'de 1 dakika

- Basamak $2-55^{\circ} \mathrm{C}$ 'de 1 dakika

- Basamak $3-72^{\circ} \mathrm{C}^{\prime}$ de 1 dakika

En son işlem olarak PCR ürünleri $72^{\circ} \mathrm{C}^{\prime}$ de $7-10$ dakika tutulmuştur.

\subsubsection{Agaroz jel elektroforezi}

PCR ürünlerinin ayrılması ve büyüklüğünün tespit edilmesi için bu teknik kullanılmıştır. PCR ürünleri ve pozitif kontrol (100 baz marker) etidyum bromür ile boyanan \%1'lik agaroz jele yüklenmiş̧ir. 1X Tris Asetat EDTA (TAE) tamponunda yürütülmüştür. 20 dakika sonra jel görüntüleme sisteminde PCR ürünlerine bakılmıştır.

\subsubsection{Genotipleme}

TNF-A gen promotör bölgesi üzerinde yer alan - 376 G/A polimorfizmi 5 ünite Tsp50 enzimi (Fermentas, USA) ile $65^{\circ} \mathrm{C}$ 'de 2 saat inkübe edilerek kesilmiştir ve oluşan uzunluklara göre genotipleme yapılmıştır (Şekil 1). 


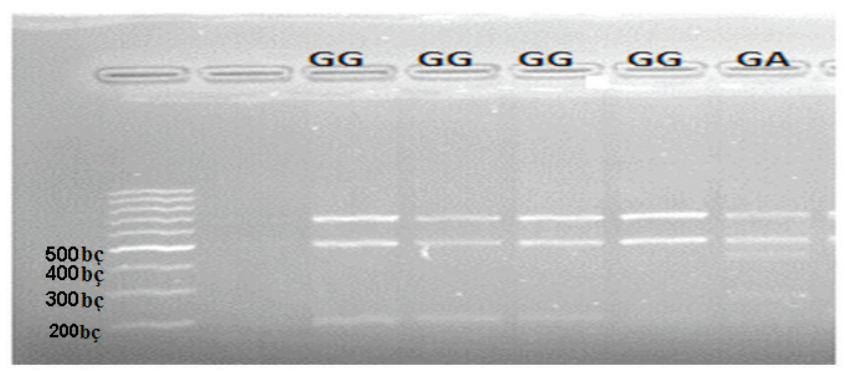

Şekil 1: Türk popülasyonunda TNF A - 376 polimorfizimin MS ile ilişkisinin agaroz jeldeki genotipleme görüntüsü

\section{3. İstatistik}

Tüm bireylerin genotipleri belirlendikten sonra hasta grubunun allel frekansları ve genotip dağılımları kontrollerle karşılaştırılmış ve elde edilen veriler SPSS 17.0 programı yardımıyla Ki-Kare testi kullanılarak analiz edilmiştir. $\mathrm{p}<0.05$ (2-sided) değeri anlamlı olarak kabul edilmiştir. Hardy-Weinberg prensibine göre değerlendirme yapılmış, fark saptanmamıştır.

\subsection{Etik Kurulu ve Hasta Onayı}

Bu çalışma için tüm hastalardan yazılı onay alınmıştır. Etik kurul onayı Marmara Üniversitesi Tıp Fakültesi Etik Kurulu tarafından verilmiştir. Bu çalışmaya katılan tüm bireylerin hakları saklıdır ve her türlü bilginin gizliliği korunacaktır. Etik kurulu sayı numarası B.30.2MAR.0.70.00.03/120062485.

\section{BULGULAR}

Çalışmamızda toplam 100 sağlıklı kontrol ve 100 hasta olmak üzere 200 birey incelenmiştir. Hasta ve kontrollerin genotip dağılımları Tablo 1'de özetlenmiştir. 100 hasta bireyden 98'inin genotipi homozigot GG olarak bulunmuştur. Sadece 2 bireyde heterozigot GA görülmüştür. Ayrıca homozigot genotip AA tespit edilmemiştir. Sağlıklı 100 bireyden ise 89'unun genotipi GG ve 11 'i heterozigot GA'dır. Aynı şekilde sağlıklı bireylerde de homozigot AA gözlenmemiştir. Bu sonuçlar değerlendirildiğinde MS hastalığı ile TNF-A - 376 genotip dağılımı arasında anlamlı bir ilişki bulunmuştur $(\mathrm{p}=0,010)$. Hasta ve kontrollerin allel frekansları Tablo 2'de özetlenmiştir. Allel frekanslarına bakıldığında kontrol grubunda $189 \mathrm{G}$ alleli ve $11 \mathrm{~A}$ alleli; hasta grubunda ise 198 $\mathrm{G}$ alleli ve 2 A alleli tespit edilmiştir. Sonuç olarak MS hastalığı ile TNF-A - 376 allel frekansı arasında da anlamlı bir ilişki saptanmıştır ( $\mathrm{p}=0.011)$. Bu anlamlı ilişki, heterozigot GA genotipi ve aynı zamanda A allelinin MS hastalığından koruyucu olduğu yönündedir.
Tablo 1: Türk popülasyonunda MS hastaları ve sağlıklı kontrollerde TNF-A - 376 polimorfizmi genotip dağılımları

\begin{tabular}{lllll}
\hline & Genotip & & MS vs. \\
\cline { 2 - 5 } TNF-A (-376) & G/G & G/A & TOPLAM & Kontrol \\
\hline Kontrol & $89(\% 89)$ & $11(\% 11)$ & $100(\% 100)$ & \\
MS & $98(\% 98)$ & $2(\% 2)$ & $100(\% 100)$ & $\mathrm{p}=0.010$ \\
TOPLAM & $187(\% 93.5)$ & $13(\% 6.5)$ & $200(\% 100)$ &
\end{tabular}

Tablo 2: Türk popülasyonunda MS hastaları ve sağlıklı kontrollerde TNF-A - 376 polimorfizmi allel frekansları

\begin{tabular}{ccccc}
\hline & \multicolumn{3}{c}{ Allel } & MS vs. \\
\cline { 2 - 5 } TNF-A (-376) & G & A & TOPLAM & Kontrol \\
\hline Kontrol & $189(\% 94.5)$ & $11(\% 5.5)$ & $200(\% 100)$ & $\mathrm{p}=0.011$ \\
MS & $198(\% 99)$ & $2(\% 1)$ & $200(\% 100)$ & \\
TOPLAM & $387(\% 96.8)$ & $13(\% 3.3)$ & $400(\% 100)$ &
\end{tabular}

\section{TARTIŞMA}

MS hastalığ1 aksonal hasarla seyreden otoimmün demyelizan bir hastalıktır. MS hastalığına genetik yatkınlık ihtimali bilim insanları tarafından defalarca araştırılmış, bu genetik faktörlerden birisinin de TNF-A gen polimorfizmleri olabileceği üzerinde durulmuştur [14-16]. Bu amaçla daha önce - 376, - 308, - 238 ve - 244 polimorfizmleri en sık araşt1rılan polimorfizmler olmuştur. Bu polimorfizmler hakkında farklı etnik gruplarda yapılan çalışmalarda farklı sonuçlar elde edilmiştir [17]. Çalışmamızda da bulgularımız gösterdiği üzere TNF-A - 376 GG genotipi ve G allelinin MS hastalarında sıklığı artmış, ancak bunun hastalık açısından risk oluşturması yönünde herhangi bir ilişki bulunamamıştır. Daha önce yapılan birkaç çalışmada da bu sonucu destekleyen bulgular saptanmasına [18, 19] karşın hastalıkla ilişkisi olduğu yönünde bulgular olan çalışmalar da mevcuttur [20, 21]. MS hastalığı ile TNF-A gen polimorfizmleri arasındaki ilişkiyi inceleyen bir kısım araştırmalar - 376, - 308 ve 238'inci pozisyonlarda düşük frekanslarda bulunan A allelinin koruyucu etkisi olabileceğini belirtmiştir [21-25] ve bizim çalışmamız da bu bulgu ile korelasyon göstermektedir ki hem - 376 GA genotipi dağılımı $(p=0,010)$ hem de A alleli frekansı $(p=0,011)$ arasındaki ilişkinin daha çok koruyucu etkisi olduğu yönündedir. Yukarıda bahsedilen çalışmalar ülkemize yakın ülkelerde yapılmış ve benzer bulgular elde edilmiştir. Farklı etnik gruplarda yapılan TNF-A promotör polimorfizmleri ile MS arasındaki ilişkiyi araştıran çalışmaların farklı sonuçlar vermesinin nedeni HLA bölgesindeki farklılıklardan kaynaklanabilmektedir[26].

Çalışmamızın zayıf noktası olarak, hasta sayımızın düşük olması ve çalışmaya katılan bireylerde kanda ve BOS'da TNF- $\alpha$ seviyesine bakarak polimorfizmlerin gerçek etkisinin ortaya koyulamaması söylenebilir. Çünkü daha önce 
yapılan bazı çalışmalar göstermiştir ki - 376 GG genotipi taşıyan organ donörleri, GA genotipi taşıyanlara göre daha fazla TNF- $\alpha$ üretmektedir [24] ve progresif MS hastalar1nın BOS'unda TNF- $\alpha$ seviyesi daha yüksek bulunmaktadır [8]. Lassmann ve ark. tarafından yapılan çalışmanın sonuçları bizim çalışmamızın aksine, MS hastalarında G allelinin daha fazla saptanmasının daha fazla TNF- $\alpha$ üretimine ve böylece myelin kılıfı hasarını artırarak hastalığın progresyonuna neden olup, oligodendroglial hücre kaybı ve demyelinizasyona ilerlemesine neden olduğunu savunmaktadır [27]. Bizim çalışmamızda da MS hastalarında G alleli daha fazla saptanmış ancak istatistik olarak anlamlı bulunmamıştır. Literatürde bulgularımızı destekleyen çalışmalar da mevcuttur [17]. Bahsedilen çalışmada, MS ile ilişkili daha fazla SNP çalışılması ve mutlaka TNF- $\alpha$ seviyeleri ile korelasyonu yapılması önerilmektedir. Çalışmamızda A allel frekansı MS hastalarında $\% 1$ civarında saptanmıştır ve daha önce yapılan çalışmalara göre daha düşüktür [19-21, 12]. Çalışmamızdaki AA genotipi, önceki çalışmalarla uyumlu olarak, katılımc1larda saptanmamıştır [20, 21].

Sonuç olarak, Türk popülasyonunda G allelinin MS hastalığı ile ilişkili olmadığı ve A allelinin koruyucu bir etkisi olabileceği düşünülmektedir. Bulgularımızı doğrulamak ve istatistiki gücünü artırmak için çalışmanın daha da genişletilmesine ihtiyaç vardır.

\section{TEŞEKKÜR}

Bu çalışma FEN-C-YLP-140312-0051 numaralı proje kapsamında Marmara Üniversitesi Bilimsel Araştırma Projeleri Birimi tarafindan desteklenmiştir.

\section{KAYNAKLAR}

[1] Noseworthy JH., Lucchinetti C. ve Rodriguez M., Weinshenker BG. (2000). Multiple sclerosis. N Engl J Med., 343, 938952.

[2] Dyment DA., Sadovnick AD. ve Ebers GC. (1997). Genetics of multiple sclerosis. Hum Mol Genet, 6, 1693-1698.

[3] Elahi MM., Asotra K., Matata BM. ve Mastana SS. (2009). Tumor necrosis factor alpha - 308 gene locus promoter polymorphism: an analysis of association with health and disease. Biochim Biophys Acta, 1792, 163-172.

[4] Zipp, F., Weber, F., Huber, S., Sotgiu, S., Czlonkowska, A., Holler, E., Albert, E., Weiss, E. H., Wekerle, H., ve Hohlfeld, R. (1995). Genetic control of multiple sclerosis: increased production of lymphotoxin and tumor necrosis factor-alpha by HLA-DR2+ T cells. Ann Neurol, 38, 723-730.

[5] Rahmanian M1, Kargar M2. Tumor necrosis factor-alpha polymorphism and susceptibility to multiple sclerosis in the Iranian population. Iran Red Crescent Med J. 2014 Dec 27;17
[6] Hurwitz BJ. (2009). The diagnosis of multiple sclerosis and the clinical subtypes. Ann Indian Acad Neurol, 12, 226-230.

[7] Kassiotis G. ve Kollias G. (2001). TNF and receptors in organ-specific autoimmune disease: multi-layered functioning mirrored in animal models. J Clin Invest, 107, 1507-1508.

[8] Sharief MK.ve Hentges R. (1991). Association between tumor necrosis factor-alpha and disease progression in patients with multiple sclerosis. N Engl J Med, 325, 467-472.

[9] Fargion S., Valenti L., Dongiovanni P. ve Fracanzani AL. (2004). TNFalpha promoter polymorphisms. Methods Mol Med, 98, 47-58.

[10] Akcali A1, Pehlivan S, Pehlivan M, Sever T, Akgul P, Neyal M. TNF-alpha promoter polymorphisms in multiple sclerosis: no association with -308 and -238 alleles, but the -857 alleles in associated with the disease in Turkish patients. Int $\mathrm{J}$ Immunogenet. $2010 \mathrm{Apr} ; 37(2): 91-5$

[11] Braun, N., Michel, U., Ernst, B. P., Metzner, R., Bitsch, A., Weber, F., ve Rieckmann, P. (1996). Gene polymorphism at position -308 of the tumor-necrosis-factor-alpha (TNFalpha) in multiple sclerosis and it's influence on the regulation of TNF-alpha production. Neurosci Lett, 215(2), 75-78.

[12] Knight JC1, Udalova I, Hill AV, Greenwood BM, Peshu N, Marsh K, Kwiatkowski D. A polymorphism that affects OCT-1 binding to the TNF promoter region is associated with severe malaria. Nat Genet. 1999 Jun;22(2):145-50.

[13] S.A. Miller, D.D. Dykes DD, H.F. Polesky, A simple salting out procedure for extracting DNA from human nucleated cells. Nucleic Acids Res. 16(3) (1988), pp:1215.

[14] Hauser, S. L. (1995). Tumor necrosis factor: immunogenetics and disease. Ann Neurol, 38(5), 702-704.

[15] Weinshenker, B. G., Wingerchuk, D. M., Liu, Q., Bissonet, A. S., Schaid, D. J., ve Sommer, S. S. (1997). Genetic variation in the tumor necrosis factor alpha gene and the outcome of multiple sclerosis. Neurology, 49(2), 378-385.

[16] Wingerchuk, D., Liu, Q., Sobell, J., Sommer, S., ve Weinshenker, B. G. (1997). A population-based case-control study of the tumor necrosis factor alpha-308 polymorphism in multiple sclerosis. Neurology, 49(2), 626-628.

[17] Bayley, J. P., de Rooij, H., van den Elsen, P. J., Huizinga, T. W., ve Verweij, C. L. (2001). Functional analysis of linker-scan mutants spanning the $-376,-308,-244$, and 238 polymorphic sites of the TNF-alpha promoter. Cytokine, 14(6), 316-323.

[18] de Jong, B. A., Huizinga, T. W., Zanelli, E., Giphart, M. J., Bollen, E. L., Uitdehaag, B. M., Polman, C. H., ve Westendorp, R. G. (2002). Evidence for additional genetic risk indicators of relapse-onset MS within the HLA region. Neurology, 59(4), 549-555.

[19] Wirz, S. A., Morale, M. C., Marchetti, B., Barr, A. M., Sotgiu, S., Rosati, G., Pugliatti, M., Sanna, M. V., Giliberto, O., Bartfai, T., ve Conti, B. (2004). High frequency of TNF alleles 238A and $-376 \mathrm{~A}$ in individuals from northern Sardinia. $C y$ tokine, 26(4), 149-154. 
[20] Fernandez-Arquero, M., Arroyo, R., Rubio, A., Martin, C., Vigil, P., Conejero, L., Figueredo, M. A., ve de la Concha, E. G. (1999). Primary association of a TNF gene polymorphism with susceptibility to multiple sclerosis. Neurology, 53(6), 1361-1363.

[21] Losonczi, E., Bencsik, K., Nagy, Z. F., Honti, V., Szalczer, E., Rajda, C., Illes, Z., Matyas, K., Rozsa, C., Csepany, T., Fuvesi, J., ve Vecsei, L. (2009). Tumour necrosis factor alpha gene (TNF-alpha) - 376 polymorphism in Hungarian patients with primary progressive multiple sclerosis. J Neuroimmunol, 208(1-2), 115-118.

[22] Drulovic, J., Popadic, D., Mesaros, S., Dujmovic, I., Cvetkovic, I., Miljkovic, D., Stojsavljevic, N., Pravica, V., Pekmezovic, T., Bogdanovic, G., Jarebinski, M., ve Mostarica Stojkovic, M. (2003). Decreased frequency of the tumor necrosis factor alpha -308 allele in Serbian patients with multiple sclerosis. Eur Neurol, 50(1), 25-29.

[23] He, B., Navikas, V., Lundahl, J., Soderstrom, M., ve Hillert, J. (1995). Tumor necrosis factor alpha-308 alleles in multiple sclerosis and optic neuritis. J Neuroimmunol, 63(2), 143-147.
[24] Huizinga, T. W., Westendorp, R. G., Bollen, E. L., Keijsers, V., Brinkman, B. M., Langermans, J. A., Breedveld, F. C., Verweij, C. L., van de Gaer, L., Dams, L., Crusius, J. B., Garcia-Gonzalez, A., van Oosten, B. W., Polman, C. H., ve Pena, A. S. (1997). TNF-alpha promoter polymorphisms, production and susceptibility to multiple sclerosis in different groups of patients. J Neuroimmunol, 72(2), 149-153.

[25] Ristic, S., Lovrecic, L., Starcevic-Cizmarevic, N., Brajenovic-Milic, B., Sega Jazbec, S., Sepcic, J., Kapovic, M., ve Peterlin, B. (2007). Tumor necrosis factor-alpha-308 gene polymorphism in Croatian and Slovenian multiple sclerosis patients. Eur Neurol, 57(4), 203-207.

[26] Maurer, M., Kruse, N., Giess, R., Kyriallis, K., Toyka, K. V., \& Rieckmann, P. (1999). Gene polymorphism at position 308 of the tumor necrosis factor alpha promotor is not associated with disease progression in multiple sclerosis patients. $J$ Neurol, 246(10), 949-954.

[27] Lassmann, H., Bruck, W., ve Lucchinetti, C. F. (2007). The immunopathology of multiple sclerosis: an overview. Brain Pathol, 17(2), 210-218. 